\title{
The cattle raiders leave us no choice: New transhumance in the Mahafaly Plateau region in Madagascar
}

\author{
Johanna F. Goetter'
}

\author{
Correspondence: \\ Johanna F. Goetter \\ Department for Environmental Economics, \\ Brandenburg Technical University Cottbus-Senftenberg, Erich- \\ Weinert-Straße 1, \\ 03046 Cottbus, Germany \\ E-mail: goetter@b-tu.de
}

\begin{abstract}
This article reports findings from a qualitative case study on the recent development of a pastoral transhumance movement in the Mahafaly Plateau region in Madagascar. Interviews with pastoralists from 26 villages are analyzed within a framework of contemporary new institutional economics to investigate pastoral mobility, as a response to the Madagascar-wide problem of cattle raiders (dahalo). The conditions for the new movement are compared to a traditional transhumance movement comprising the same actors but in reverse geographical direction. Contrary to many previous studies from Madagascar, the results reveal that property rights regarding access to ancestral land are not a constraint to pastoral mobility. The new transhumance movement was enabled by pro-social norms of solidarity, guest rights and unconditional hospitality (fihavanana) shared by the pastoralists in the region. Additional vital elements are mental models of kinship (raza, longo) and the formal indigenous institution of trust creation by sincerity oaths (titike, kine). However, frequent cattle raids have led to social change and an environment of mistrust; placing social constraints on pastoral mobility. Hospitality and guest rights are increasingly bound to kinship relations, and the pastoralists' interpretation of kinship has become narrower. These social constraints are far more relevant to the new movement than to the more institutionalized traditional transhumance. The findings illustrate how Madagascar's cattle raiding problem has influenced the rural society's social norms and mental models. The study highlights how supportive social norms and fitting shared mental models influence people's capacity to adapt, especially in sociocultural settings ruled by informal indigenous institutions.
\end{abstract}

\section{RÉSUMÉ}

Dans une étude de cas qualitative, l'élaboration récente d'une transhumance pastorale à travers le plateau Mahafaly dans la région subaride du sud-ouest de Madagascar a été analysée. Des interviews ont été menées avec des bouviers de 26 villages de la région afin de comprendre comment cette nouvelle forme de transhumance est apparue et comment elle a été élaborée afin d'identifier les similarités et les différences par rapport à la transhumance traditionnelle qui reste d'actualité et suit la même direction mais en sens opposé. Les interviews ont abordé les expériences personnelles des bouviers sur la pratique de la nouvelle transhumance ou la transhumance traditionnelle ainsi que leur perception des menaces que représentent les voleurs de bétail (dahalo, en dialecte régionale malaso). Les avantages et les limites de la nouvelle transhumance ont également été globalement abordés. Les personnes résidentes de la zone littorale ont été interviewées pour comprendre comment elles percevaient la nouvelle transhumance et comment elles accueillaient les bouviers dans leurs villages. Contrairement à de nombreuses études menées à Madagascar, les résultats obtenus ici montrent que les droits de propriété portant sur l'accès aux terres ancestrales ne sont pas une contrainte pour les mouvements pastoraux. La nouvelle forme de transhumance est encore peu institutionnalisée mais favorisée par des normes pro-sociales de solidarité et d'hospitalité inconditionnelle (fihavanana, en dialecte régionale filongoa), de partage des ressources fourragères, de modèles mentaux de liens de parenté (raza, longo) et d'institutions autochtones formelles régissant les rapports de confiance mutuelle (titike, kine). Néanmoins, l'extension et une plus grande institutionnalisation de la nouvelle transhumance sont limitées par les modèles mentaux portant sur les droits des bouviers ainsi que par les changements sociaux induits par la forte croissance des vols de bétail, de sorte les institutions qui régulent la mobilité des bouviers sont affaiblies. L'hospitalité et les droits minimums sont de plus en plus limités aux relations filiales, et leur interprétation en ce qui concerne les bouviers a été bien réduite avec un accueil refroidi en ce qui concerne les bouviers allochtones, plus particulièrement sur la nouvelle transhumance. Cette étude montre comment les problèmes de transhumance du bétail ont influencé les normes sociales et les modèles mentaux des sociétés rurales. Elle 
a révélé la manière avec laquelle des normes sociales et des modèles mentaux spécifiques influencent la capacité d'adaptation des gens, plus particulièrement dans des milieux socio-culturels gouvernés par des institutions locales informelles.

\section{INTRODUCTION}

Pastoralists around the world are known to adopt flexible management approaches to cope with unexpected events and changing livestock-raising conditions (Fernandez-Gimenez and Le Febre 2006). One important strategy for coping with variable water and pasture availability is pastoral mobility, including long-range, predictable seasonal movements called transhumance (Behnke et al. 2011). In the Mahafaly Plateau region of southwest Madagascar, the Tanalana people living on the coastal plain still practice their ancient tradition of transhumance (Battistini 1964). The Tanalana herders spend approximately four to six months of the year further inland on the plateau, where fodder is comparatively more abundant (SULAMA 2011). In recent years, a previously unreported transhumance movement in the inverse direction to the traditional one has emerged: in order to escape cattle raiders, herders from the plateau temporarily move to the coastal plain. This pattern will hereafter be referred to as 'inverse transhumance'.

Cattle raiding has been known as a feature of pastoral life in Madagascar since the publication of Robert Drury's Journal (Defoe et al. 1890). Since then, it has appeared in the literature with increasing frequency (Ribar 1926, Faublée 1941, Michel 1957, Rabearison 1965, Randrianjafizanaka 1973, Randrianarison 1976, Hoerner 1982, Fieloux 1987, Fauroux 1989, Elli 1993, Kaufmann 1998, de Saint-Sauveur 2002, Fauroux 2003, Rasamoelina 2006, McNair 2008, Rakoto 2010, 2011, Scheidecker 2014). In the past, cattle raiding had mainly cultural motives (Fauroux 1989). Cattle are the main source of capital and social status in the Mahafaly Plateau region (Fauroux 1997), and stealing them has long been a 'local sport' of young men (Battistini 1964). Today, however, attacks by organized gangs of cattle raiders, so called dahalo or malaso, have reached new dimensions in terms of economic impact and violence in Madagascar. In the most affected southern regions, their attacks have led to the displacement of villagers (OCHA 2012), and to an overall decline in economic activity (Fafchamps and Minten 2006, Rakoto 2010). Cattle raiding has become a topic frequently discussed in the national and even international media (cf. BBC News 2008).

Although a small number of studies on local adaptation to cattle raiding in Madagascar do exist (de Saint-Sauveur 2002, Tubau 2011), new pastoral movements have not been reported to date. On a global level, cattle raiding is known to affect many pastoral groups, mostly in Africa (Blench 2001, Bollig 2006, Beyene 2009, Schilling et al. 2012). Yet recent trends towards greater pastoral mobility have mainly been described as climate change adaptation strategies (Agrawal 2010, Scheffran et al. 2011, Upton 2012).

This case study analyzes the factors that enable, shape, and restrict the emergence of the inverse transhumance movement from the Mahafaly Plateau to the coastal region. In Madagascar, access to pastoral land in general also means access to 'ancestral land'. This tanin-drazana is understood as "(...) part of Madagascar's national motto, with the zebu cattle as its emblem" (von Heland and Folke 2014: 259). Customary property rights and legitimate use of ancestral land are typically limited to the members of the local 'autochthonous' clans (Muttenzer 2006, Evers and Seagle
2012). Access and rights to land for newcomers and evolving conflicts with the owning clans are mainly solved by formal agreements of clan councils (von Heland and Folke 2014). In the study area's coastal region, access to land and especially to scarce fodder stocks is a source of frequent conflict. It is thus expected that the moving herders' need to obtain a share of these fodder stocks will require additional formal agreements with the communities living on the coastal plain.

Pastoral societies in Madagascar and other regions, however, do not principally base pastoral mobility, and the related access to resources on such formal agreements alone. Essentially, in most pastoral societies the boundaries of resource territories are flexible, the conceptions of legitimate user groups are fuzzy (Bromley 2006, Fernandez-Gimenez and Le Febre 2006), and the relationships between interacting groups of herders are dominated by solidarity, reciprocity, and kinship (Thébaud and Batterbury 2001, Bollig 2006, Di Falco and Bulte 2013). In Madagascar, the "social cornerstone" of the society (Fritz-Vietta et al. 2009: 93) is the concept of fihavanana, embracing meanings of solidarity, social harmony, tolerance, friendship, union, mutual responsibility, reciprocity and kinship (Evers 2006, Schachenmann 2006, Fritz-Vietta et al. 2011, Kneitz 2014).

Alongside the social value of fihavanana and formal laws and rules on land and resources, the inverse transhumance movement is expected to be shaped by additional factors. People's adaptation options are known to be influenced by a range of social and personal variables that include knowledge, risk perception, moral values, habits, social status, power relations and traditional group procedures (Adger et al. 2009). To analyze the broad spectrum of factors outlined above, a framework from 'contemporary new institutional economics' (Vatn 2005) was chosen: Social interaction, but also all other behaviors of individuals, is explained as being structured and regulated by so-called institutions in the form of rules, values, routines, norms and mental models.

The paper is divided into three parts. The first part describes the conceptual framework and methods, and gives an introduction to the study area. The second part presents the data on inverse transhumance, as well as an overview of traditional transhumance, the local perception of cattle raiding, and ongoing social change. The final part discusses the character, conditions and limitations of inverse transhumance in comparison to traditional transhumance and in relation to the raiding problem and social change.

\section{METHODOLOGY}

CONCEPTUAL FRAMEWORK. Within the framework of contemporary new institutional economics (Vatn 2005) adopted here, the action of an individual is seen as being embedded in a web of institutions. These institutions on the one hand constrain certain patterns of behavior, but on the other hand enable other patterns. They allow the individuals to predict the likely behavior of others and adapt their own behavior to one that is supposedly socially accepted (Dequech 2006). Institutions can be classified according to their degree of formality: Formal institutions are understood as socially transmitted and customary normative injunctions evidently known to the individual (Hodgson 2006). Along the same lines, formal institutions are legal rules which are created and enforced through sanctioning by some explicit collective process (Knight and Sened 1995, Schmid 2004), in the Malagasy 
context, for example, the local rules created by the village communities (dina). Informal institutions are immanent normative dispositions (Hodgson 2006). Deviations to informal institutions cannot be formally sanctioned, but their enforcement relies on expressed disapproval of other individuals, for example, through gossip and ostracism (Schmid 2004, Eggertsson 2013). Informal institutions include codes of conduct, customs, routines, shared mental models and social norms, the latter being defined as "social standards of behavior and/or thought" (Dequech 2006: 473). Mental models represent the people's beliefs, interpretations of the world, and views of causal relationships (Denzau and North 1994, Bromley 2006). Mental models can be seen as "the crucial factor in explaining the choices people make" (Knight and North 1997: 216) and as enhancing the "durability, power, and normative authority" of all other types of institutions, while the other way round those institutions standardize mental models by creating "strong mechanisms of conformism and normative agreement" (Hodgson 2006: 7). As an example of informal institutions, the Malagasy concept of fihavanana embraces mental models about the definition or character of kinship, friendship and hospitality, and related social norms that define what good behavior in line with fihavanana means.

Processes of institutional change and the emergence of institutions differ between formal and informal institutions: A formal institution is consciously crafted and changed, for example, by copying another institution from a different setting (Ostrom 2005). Alternatively, people implicitly use their underlying mental models to gradually adapt an institution until they feel that it 'fits' again (Mantzavinos et al. 2004, Brousseau et al. 2011). The change and adaptation of informal institutions is driven by learning, changes in the power of actors, and the institutions' functionality (Schmid 2004). Informal institutions, especially social norms or customs can even "die in an evolutionary process (...) without people being aware of the process" (Schmid 2004: 7, 267).

STUDY AREA. The Mahafaly Plateau region is situated in southwest Madagascar, in the dry forest ecoregion south of To-

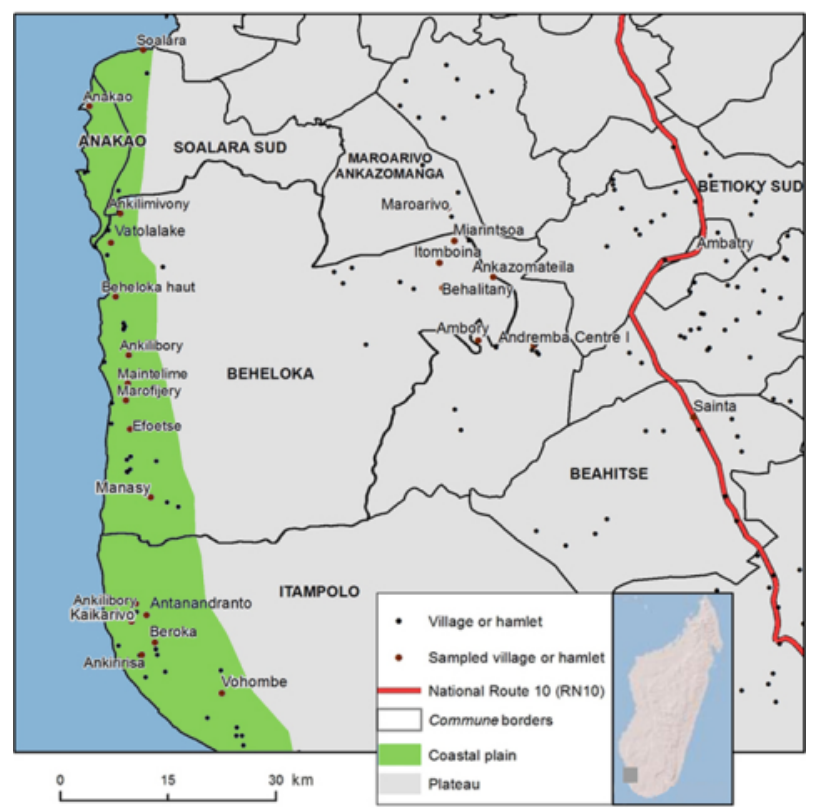

Figure 1: Map of the study region and sampled villages and hamlets (source: SuLaMa). liara. The region can be divided into two zones: the plateau itself and the coastal plain.

According to the official ethnic classification of Madagascar, the region is mainly inhabited by the agro-pastoral group of Mahafaly and its sub-group of Tanalana (Battistini 1964). However, during field research, people clearly expressed a local view of Tanalana as an independent group. According to the villagers' classification, the agro-pastoralists on the coastal plain are Tanalana, while the villages on the plateau are both mixed and pure Tanalana and Mahafaly communities. The semi-nomadic Vezo fishermen are another ethnic group living in the region. Inter-ethnic and inter-regional marriages are common and create vast familial bonds between people of different regions and ethnic groups.

The Tanalana and Mahafaly people are subsistence farmers and also engage in keeping poultry, goats, sheep and zebu-cattle (Bos indica) (Battistini 1964, SULAMA 2011). The Tanalana villages on the plateau were founded around two generations ago, by Tanalana people from the coastal plain who moved in search of better conditions for agriculture and livestock keeping (Esoavelomandroso 1989). The predominantly red soils and precipitation rates between $400-450 \mathrm{~mm} /$ year on the plateau allow better yields than on the coastal plain with only $300-350 \mathrm{~mm} / \mathrm{year}$ and sandy soils. On the plateau, the wide savannas allow cattle to graze freely the whole year round.

On the coastal plain, grass quantity and quality allow grazing for only around two months of the year. For four to six months, the cattle are fed on sliced branches of planted raketa cactus (Opuntia spp.), and wild or planted samata trees (Euphorbia stenoclada, Figure 2). In order to stimulate the growth of samata, the herders have been removing other shrubs, turning the region into a "samata landscape" (Kaufmann 2004: 351).

Livestock is the fundamental form of material wealth in the region (Fauroux 1997, Hänke and Barkmann, In litt.). In 2012, approximately $60 \%$ of the region's households owned livestock, but only $40 \%$ of the households were able to raise cattle. Depending on the family's economic situation, the number of cattle per household varies between 1 and more than 200 animals, with an average of 17 heads (Neudert et al. 2015). Raising cattle is a family affair, where the animals are generally herded by the sons while ownership and decision rights are mainly in hands of the father.

The social and political organization of the Tanalana and Mahafaly people is based both on the traditional ethnic structure of common ancestors (raza) with clans and subordinated lineages,

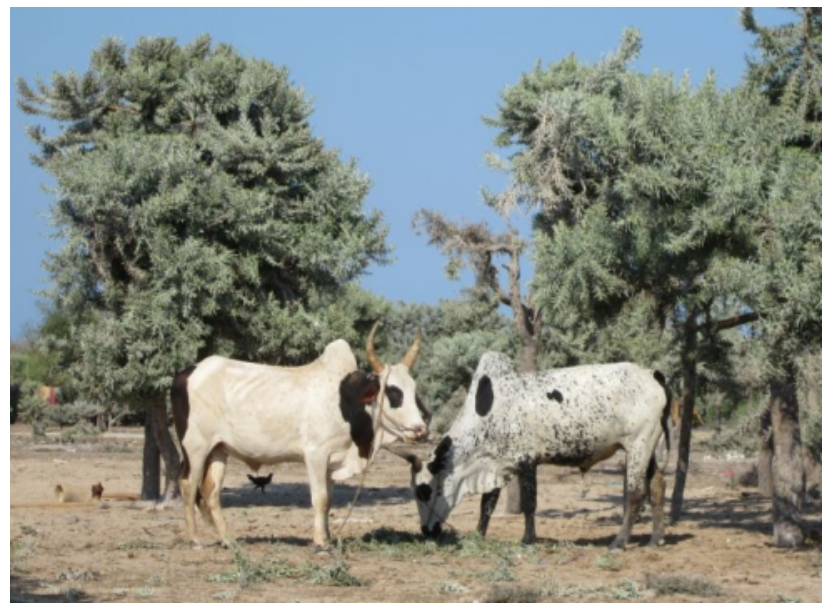

Figure 2: Cattle eating chopped samata (Euphorbia stenoclada). 
as well as the territorial structures of the state-run administration. The smallest administrative unit in Madagascar is the fokontany. It usually covers a village and its surrounding hamlets. A fokontany is officially run and represented by a selected head (chef de fokontany). Decisions on the village level are however mainly taken by the village community (fokonolo) in open meetings or the group of elders. The villagers rely mainly on two groups of social networks: their formal kin group (raza) and the longo. In the study region, unlike other parts of Madagascar (Astuti 1995), longo is not used as a synonym for the formal kin group comprising people from the extended family up to the overall ethnic group (Eggert 1986). Longo describes a personified kin group consisting of relatives, friends and in general all people with whom one has a good relationship (fihavanana, in the regional dialect filongoa). In Madagascar, the character of kinship is 'cumulative' (Southall 1986, Astuti 1995), allowing new alliances for example by marriage or the birth of children. Identity and kinship are understood in a broad sense of being created throughout one's life and "settled definitely perhaps only some considerable time after death" (Bloch 2005: 65). Identity is "fluid" (Marcus 2008: 88), changing with a persons' environment, association, choice and need (Bloch 2005, Marcus 2008).

INTERVIEWS. The study was conducted during three periods

of field research in 2012 and 2013, preceded by a preparatory field trip in 2011. The analysis is based on 81 open and semistructured interviews with people from 10 villages on the plateau and 16 villages on the coastal plain (Figure 1).

Moving herders and cattle owners from the plateau and the coastal plain were interviewed about the transhumance movements in general and their personal ways of conducting the move. The conversations covered the choice of destinations, courses of action, related customs, costs, property rights to fodder, and the feeling of living temporarily 'abroad'. Non-moving herders on the plateau were interviewed about their reasons for not migrating. People of the coastal plain were asked their opinion about hosting the new guest herders in their village. The perception of the problem of cattle raiding was also discussed. The interviewees were, with five exceptions, males. Ages ranged between 15 and 88 , with the majority being between 30 and 60 years old.

All interviews were held by the author with the help of research assistants consecutively interpreting between the local Malagasy dialect and English. Both assistants knew the dialect very well, as one grew up on the plateau, and the other has been working in the study area since 2011 and living in Toliara since 2004. Cattle owners and herders were identified with the help of local guides. Most interviews were held in the presence of the author, an assistant, a guide and one interviewee. The guides were mostly young men under 20 who did not participate in the interviews. In three interviews, however, two older guides (age 37 and 57) added information and views, and in one case took over the interview with a teenager. Two interviews were held with two close relatives (father and son, couple), and four interviews with two, two interviews with three, and six interviews with four or more people who happened to be together at the time of interview.

During the interviews, comprehensive, often word-for-word notes were taken. The notes were then digitally transcribed by the author, and if required replenished by the interpreter with help of audio-records of the interviews. An inductive content analysis
(Patton 2002) was done using the QDA software Atlas.ti to code and theme the transcribed data. The analysis is underpinned with some data from a region-wide household survey undertaken in 2012 (Neudert et al. 2015).

\section{RESULTS}

CATTLE RAIDING AND SOCIAL CHANGE. In the perception of all interviewees, the problem of cattle raiding started recently or has at least increased a lot in the last decades (Supplementary Material). As most interviewees agreed, cattle raids have always taken place in the region, but today the raiders would even "kill the people" and "steal the chickens". Of the interviewed plateau villagers, 11 had already been victims of raids, several more than once. All others reported raids having happened to relatives or other villagers. According to the interviewees, raiding is today mainly done by armed gangs from the neighboring Onilahy region northwest of the plateau. Cattle raids are far less frequent on the coastal plain, probably because the Onilahy region is farther away. The raiders attack especially in the dry season when the water level of the Onilahy River is low and it is easy to cross. Some communities on the plateau have recently employed soldiers or gendarmes to protect their people and animals. Nevertheless, most people are still very frightened of the raiders as they are said to wear extremely powerful talismans (odigasy) and thus survive all shootings without any wounds.

Asked about the reason for the increase in raids, the people of the coastal plain mainly accused state agencies and the government of not combating the raiders and of being idle or corrupt, however without mentioning the 2009 political crisis. Increased cattle raiding is also perceived as associated with a general process of social change: The plateau villagers more often blamed the 'bad youth', reporting that many young men make friends with suspicious strangers and serve them as drivers providing information about the whereabouts of the local cattle herds. Others are said to squander their money and then search for opportunities to make a fast profit by stealing on their own or at the command of a gang leader. Interviewees throughout the study area complained that the youth pay no heed to their parents' or elder's reprimands for stealing or other bad behavior: "It is a problem of generation. The sons of parents are strong now, they decide to steal." (58: 45, male, age: 60). "In the past, the children respected their parents (...) But today, the children even kill their parents when these try to intervene." (102: 1, male, age: around 20)

Throughout the region, the fear of having one's cattle stolen by order of an envious villager is commonly reported. A general rise in envy and 'bad spirits' was noted, coupled with a loss of social cohesion and traditional values like altruism, solidarity and helpfulness: "Before, the relationship and living together of the people (...) was important and strong, (...) today people don't care much about life in the community and the relationships are frail, even inside the family." [76:51, female, age: 17]. Statements like "the people do not love each other anymore" (fa tsy mifankatea sasy ty ndaty) were often made and explained as the result of modern times where people "think they are independent" and only "do what they want".

Although the coastal plain is primarily affected by clandestine theft rather than violent raiding, many stories about attacks on the plateau by infamous raiders circulate even here. Thus, the people are increasingly wary of all strangers and poten- 
tial local 'chauffeurs'. In February 2013, a ritual of sincerity oaths (titike) was organized in order to prevent an involvement of the Tanalana people in raids. Titike are traditionally realized on the level of a village community. This time, however, it embraced all Tanalana clans. On the plateau, such sincerity oaths (here also called kine) were also realized frequently, but did not go beyond the village level. Some plateau interviewees lamented that the titike would anyway no longer have the expected effects, as many young men do not believe in it, or if so, would avoid taking part.

TRADITIONAL TRANSHUMANCE FROM THE COASTAL PLAIN TO THE PLATEAU. Reasons for moving and time frames: Traditionally, the cattle of the coastal plain are moved to the plateau every year in the practice of transhumance (excluding chard oxen). Only rarely, when the plateau's grass was worse or the coastal grass better than usual, did some herders decide not to move. Today, for fear of raids on the plateau, some herders decided not to move anymore or not every year. From a sample of 90 cattle owners from five villages of the Commune of Beheloke (unpubl. survey data from 2012), 73\% send their cattle on transhumance every year, $9 \%$ less frequently, and $12 \%$ never. The average size of herds that never move is much smaller ( 2.5 heads) than that of herds that do move (17.7 heads). The transhumance season starts at the end of November or beginning of December, when the quality of coastal grass and samata fodder is low, but the beginning of rainfall on the plateau promises good-quality grass there. Traditionally, the herders return between May and June. Since around the year 2010, the rising incidence of raider attacks on the plateau has prompted many coastal herders to return home earlier (between January and April).

Conditions for staying on the plateau: The herders' journey from their home villages to the destinations on the plateau takes about one-and-a-half to two days by foot (between 40 and 70 kilometers). All movements back and forth between the home village and those destinations have to be officially permitted and registered by the respective chefs de fokontany in every herder's personal 'passport' (pasiporon-dia). This exercise book with officially stamped entries for every adult man or woman was regionally introduced in order to enhance security, and especially to prevent trafficking in stolen cattle. Officially, it should document the authorization and realization of all movements between villages, as well as selling of animals. In practice, registration in the passport is often only considered necessary by the hosts and the guest herders when these are not yet personally known in the village. The 200 Malagasy Ariary ( $\$$ US $=3,097$ Ariary, 9 October 2015) paid per registration are the only fees related to transhumance. Only for the destination of Andremba were there reports that in order to ensure a good relationship, some herders arriving for the first time voluntarily offered money or a goat to the local community. Recently, many cattle owners engage a non-local policeman or soldier (from Toliara or Betioke) to protect their herd during the stay on the plateau. As this can cost up to 200,000 Ariary per month, some cattle owners share the costs by joining their herds.

There are no special guest rules that the herders have to follow when staying on the plateau. Local ancestral or community rules (lilyn-draza, dina), customs (fomba) and common expectations about good behavior are the same as on the coastal plain. It was reported that sometimes groups of newcomers performed the common ritual of sincerity oaths (titike) with the host community. However, this ritual is seldom perceived as necessary be- cause herders are only considered to be real newcomers when neither they nor their close relatives or ancestors have stayed in the village before: "The raza [kin group, clan] is already staying here since long ago, so everybody can come and stay just like this. But the really new people should show their passport and do a titike." [45: 29, age: 55].

The Tanalana people from the coastal plain are guests both in villages inhabited mainly by Tanalana, as well as by Mahafaly people. Their relationship is closest with the Tanalana villages. Interviewees from both the coastal plain and the plateau considered all Tanalana people as descendants of the same ancestors, and therefore 'all one kin'. This formal kin group (raza) was sometimes expanded to all people from the Mahafaly Plateau region. The interviewed host villagers practically did not perceive any herder as completely unfamiliar or un-kin, as they were said to be at least 'a longo (friend or relative) of somebody' or 'known'. However, it was never stated that being kin or 'known' was a prerequisite for staying somewhere; on the contrary this was denied: "Some have [longo here], others don't. They just follow their friends from the coastal plain coming here." [79: 97, age: 62]. "[Somebody without longo here] must go to the chef de fokontany and say "I want to stay with my cattle here, and as I have no father or mother here, you are my family." [68: 42, age: 57].

Choosing destinations: During their stay on the plateau, most herders spend the night outside on the grazing grounds. The herders have the right to select their grazing areas freely and use fodder and water free of charge. The few big plateau villages like Itomboina or Andremba are frequented by hundreds of herders from the coastal plain and in some hamlets the number of guests exceeds the number of villagers. Most herders only frequent a small set of neighboring villages with choices being based mainly on practical considerations, especially travelling distance, the local availability of fodder and water, and, more recently, also the local security situation. Villages with a reputation for being risky became visited less (e.g., Andremba) or not at all (e.g., Ambatry). Among the more secure villages with good grass and water supply, many herders choose a place where they have longo. If the herders fall victim to raids, the longo are expected to help them to get the stolen animals back. In general, interviewees did not make a distinction between longo in the sense of relatives or in the sense of friends. Only three interviewees stated that they no longer consider their friend-Iongo on the plateau as real longo, due to their belief that in the current situation of general insecurity on the plateau, even their friends might be capable of stealing their cattle. Besides the practical considerations for choosing a destination, for some herders the most important factor is that they follow their personal or ancestral tradition or custom (fomba, fomban-draza): "It does not [depend on longo], it depends on your fomba [where to go]." [84: 10, male, age: 49].

INVERSE TRANSHUMANCE FROM THE PLATEAU TO THE COASTAL PLAIN. Reasons for moving and time frames: The transhumance movement in inverse direction from the plateau to the coastal plain turned out to have started as far back as 30 years ago (Supplementary Material). However, unlike the situation today, only a small number of Tanalana herders from Miarentsoa and Itomboina were involved at that time. Those herders were said to be motivated by the coastal plain's good conditions for cattle raising, specifically the coastal fodder plants (samata) and a 
higher and thus healthier salt content in the water holes. In the 1990s, recurring droughts on the plateau prompted more herders to move to the coastal plain. Since 2000 , and especially since 2010, this movement has gained pace and escaping the raiders has become the crucial motive.

At the time of the fieldwork, whether herders go on inverse transhumance or not is highly varied between different villages and ethnic groups. In the Tanalana villages of Itomboina and Miarentsoa the majority of herders practice inverse transhumance: of the 31 cattle-raising households sampled during the 2012 household survey, 16 move every year, three occasionally, and only 12 never. Of the 19 households that do move, five declared that they had done so "less than five years ago", two "less than 10 years ago" and 12 "more than 10 years ago". Those people who decide not to move have on average smaller herds than those who do move (13 versus 20 heads in Miarentsoa, and four versus 19 heads in Itomboina).

Most of the interviewed herders practicing inverse transhumance reported that today moving is no longer optional, but that "the raiders leave us no choice" [24: 37, male, age: around 60]. Nevertheless, in many Mahafaly villages it is only single herders that move (e.g., in Maroarivo), and in the big Mahafaly village, Andremba Centre I, no herder going on inverse transhumance could be found.

Herders who started to move comparatively early were asked if they had shared their experience and reported to have only talked with close family members. On the other hand, asked how they got the idea or made the decision to start moving, herders only rarely explained that their start was triggered by the experience of other moving herders. One interviewee, the first moving herder from a Mahafaly village, explained that he had formed the idea while observing herders on traditional transhumance. Two interviewees stated that going on transhumance to the coastal plain was their fomba (tradition/custom), although with very different time references: While a group of interviewees reported the existence of a fomba since the time of their grandfathers, a couple declared moving to their ancestors' place on the coastal plain for four years as their fomba. Regarding the general understanding of fomba, many interviewees presented the perception that fomba are not stable or necessarily long-standing, and that 'new fomba' easily emerge, often out of 'old fomba' that change following 'the life of the people' and 'the development'.

The moving herders leave the plateau between April and August. The dates for moving back and forth and the overall duration of inverse transhumance (between two and ten months), are decided individually by the herders. Factors taken into account are, first, the security situation on the plateau (rumors about raiding attacks, existence of soldiers in the home village), second, the resource endowments for buying fodder on the coastal plain, and third, perceiving transhumance as a burden, for example due to being away from one's 'own country'.

Conditions for staying on the coastal plain: Similar to traditional transhumance procedures, plateau herders moving to the coastal plain need to register with their 'passport' at the chefs de fokontany. Both for transhumance guests on the plateau as well as guests on the coastal plain the registration was predominantly described as some kind of 'annoying duty', but never as a constraint to transhumance or mobility in general. One interviewee from the coastal plain reported the case of plateau herders staying in the bush and avoiding entering the village (and thus having to register), probably because their herds comprised stolen animals.

After arriving in a host village, nearly all herders have to perform the traditional ritual of sincerity oaths (titike) to build mutual trust with the villagers. Unlike the situation during traditional transhumance on the plateau, where most herders can build on a titike ritual already performed by their relatives or ancestors, the titike ritual is frequently performed on the coastal plain. On the plateau, the few titike rituals performed today are mainly held by groups of 'newcomers' rather than individuals, but this is not feasible in the case of inverse transhumance. On the coastal plain, the rituals are performed by individual herders, firstly, because the herders' individual first arrival in a village varies highly in year and month and, secondly, because the comparatively small number of moving plateau herders are dispersed among more than 30 coastal villages, so that there are only between one and ten guest herders per village. The villagers do not demand a titike from the many fodder guests from other coastal villages. In the view of one chef de fokontany from the coastal plain, the reason for this difference is that people from the plateau are "more often friends of raiders" [84: 9, male, age: 49].

Unlike traditional transhumance, moving herders spend the night inside the village with their longo or in their own hut. Water is free of charge, but most fodder has to be bought. Fodder consists of private stocks of raketa (prickly pear), and privately as well as commonly owned samata trees. Samata is mostly preferred over cactus, as the latter is more expensive and besides chaffing also requires burning off the spines. The open-access community stocks are generally depleted after the first month of the feeding season, so that most plateau herders can use them only in the first days or weeks after their arrival. If economically possible, many also prefer to feed exclusively bought private fodder that is generally of better quality. Prices are determined principally by negotiation between seller and buyer and the overall supply in the village. The reported prices for an amount of samata that feeds 15 cattle for 5 months range between 17,250 and 855,000 Ariary or, if paid in cattle, between 0.2 and 6.3 animals (mainly two-year old animals). According to interviewees, an increasing scarcity has led to a considerable rise in prices in the last five years. Herders living for many months in the same village reported having received a piece of agricultural field from their longo, but had never established their own fodder plantation.

Traditionally, the use of the community stocks is free for all guests, regardless of their ethnic group or longo relations. Many locals claimed that the guests selfishly overuse the samata trees, irrespective of whether they came from the plateau or another coastal village. However, most interviewees argued that the community stocks should be kept open to all guests and only one person directly expressed a wish to limit the use of community stocks to residents. While the villagers work on the establishment and enforcement of local community rules (dina) for the distribution of samata among themselves, the topic of guests' rights had not been discussed up to the time of the fieldwork.

Choosing destinations: In contrast to traditional transhumance, there is no pattern of every plateau village being linked to a typical transhumance destination on the coastal plain. Many herders also shift between several villages in search of good, cheap cattle fodder. Besides personal fodder purchasing capacity, 
the destinations are individually chosen on the basis of the walking distance from home and the existence of some kind of longo.

Impediments to moving and kinship relations as a precondition: Although all the interviewed moving herders do in fact stay at the place of some longo (principally family in law), their personal views on the importance of having longo or not having longo being an impediment to going somewhere are highly contrasting. The same variation in arguments and opinions was found among interviewed inhabitants of the coastal plain. The interviews did not reveal any differences between the views of people from the coastal plain versus the plateau, or any other pattern (e.g., younger versus older people). The following section presents the stated opinions in detail, first from the perspective of being a guest on the coastal plain, and then from the perspective of hosting herders from the plateau.

The perspective of plateau people as potential guests. Similar to traditional transhumance, staying with longo is the fomba and makes organizing one's stay much easier. But even more importantly, many moving herders claimed that only their longo would help them if a problem arose, or that they did not trust other people: "You can't go where you don't have longo [...Only] the Iongo don't kill you." [87: 26, male, age: over 50]. The importance of longo was however also directly rejected: "[Where to go] is not a question of Iongo, but of fodder." [23: 32, male, age: 50]. Given the importance of longo as discussed by moving herders, one would expect this aspect to arise in the discussion with non-moving herders. However, only one interviewee directly argued that he had no trustworthy longo on the coastal plain and thus no destination to go to. All other interviewees, including those from Andremba Centre; where up to the time of the fieldwork nobody had moved, did not cite lacking security given by their longo as part of their personal reasoning. This type of impediment was only mentioned by those not personally affected: "Some people here don't go anywhere (...) It is not good when you go where you don't have longo, because then you are scared." [88: 5, male, age: 55]. Other interviewees stated that it would indeed be strange to stay somewhere without knowing anybody, both for themselves and for the host community. However, this would not be an impediment, as all plateau herders had at least one friend somewhere on the coastal plain or could make one for that purpose. Only one person who did not move claimed that it was not enough to have friends to stay with, and that one needed relatives: "Your friend might inform the raider to steal your cattle. So now, we don't trust the friends anymore, because this happened to four people from here." [86: 9, male, age: 33].

Besides enjoying greater comfort and security when staying in a village with longo, several interviewees from the coastal plain also argued that having longo is a prerequisite for the right to stay. In turn, on the plateau, this type of impediment was only brought up on enquiry, and only acknowledged for people from other villages: "Here, there is no problem, because people from the coastal plain come here [Andremba], and people from here [neighboring Ankilimasy] go there. But there are no people from the coastal plain going to Maroarivo, so for people from there it's different." [95: 7, age: 46]. "The people from north of Andremba are not originally from the coastal plain and so they don't have family there, and so the villagers don't know them and might think they arrived in order to steal their cattle. (...) When the first person from Maroarivo arrived there, the community (...) told him not to come back again." [73: 67, age 57]. Other people however argued that a general guest right to stay somewhere does indeed theoretically exist, but has no practical relevance due to the high level of familiarity among all people of the region: "[A:] People without longo can also go there, they just stop at the chef de fokontany and he shows them a family to stay with, and then (...) he makes a titike-ritual (...) But this is a rare case, because all people have longo there. [B:] Maybe for people from very far away it is different, like for people from [the commune of] Masiaboay." [50: 39, age A: around 60, age B: 57].

When asked to give their personal reasons for not moving, the non-moving herders mostly explained that their animals were unable to cope with the samata fodder and the salty water at the coast: "The coastal plain is my ancestor's land, but my cattle can't adapt to it." [80: 38, male, age: 39]. This impediment for moving was also cited by villagers of Itomboina and Miarentsoa, both villages where the first herders had in fact started moving to benefit from the specific conditions at the coast. A number of people stated particular reasons for not moving: their own village on the plateau was safe enough, the coastal plain was just as risky as the plateau, being a victim of raids was destiny or a decision of God, cattle raiders would only attack 'bad people', and one declared he was not able to even temporarily migrate from the land of his ancestors.

The perspective of people from the coastal plain as potential hosts. In the coastal plain region, all interviewees stated that the plateau herders staying in their village were longo of another villager. The question of whether, theoretically, herders without longo would also be allowed to stay was answered with inconsistent arguments, similar to those given by the plateau people. Some declared that, in general, every unsuspicious herder arriving from the plateau would be received regardless of being a longo or not: "Everybody from there with a clean passport [i.e., without inconsistencies] is welcomed here." [85: 15, male, age: 54]. This was sometimes specified with the argument that the same plateau villagers also host people from the coast on transhumance: "Today, the people from there replicate what we did: We went there and were welcomed, now it is the other way round." [21: 22, male, age around 40]. When asked why there are only Tanalana but no Mahafaly guest herders staying in their village, the interviewees from the coastal plain mainly argued that the Mahafaly people 'don't have the custom' of going to the coastal plain, or - echoing the non-moving plateau herders - that the plateau cattle are not able to digest samata. Others stated that only Tanalana people or the villagers' longo should be guests, or argued in the sense that all Tanalana are longo or known everywhere: "All people from Miarentsoa [Tanalana-village] know all people on the coastal plain, so they can go everywhere. If you know one or more persons here, you can tell them that you come here for the samata, that's okay." [42: 63, male, age: 50-60].

Limitations of a general guest right to stay somewhere were mainly related to the fear of cattle raiders from the plateau. One chef de fokontany reported that his village community had denied permission to stay to two herders without longo who had come from a commune further away than usual (Beahitse). He argued that the villagers would receive longo according to the ancestors' custom (fomba), but would not welcome unknown people as they "don't like raiders". Residents of another village repeatedly 
claimed that they would not accept any guests from the plateau, accusing the guests of not following the local rules of good behavior. However, according to other interviewees there are indeed guest herders from the plateau staying in that village.

\section{DISCUSSION}

The case study compared two current transhumance movements within the same region in southwest Madagascar: The traditional one from the coastal plain to the plateau, and the comparatively new one in the inverse direction from the plateau to the coastal plain. The results reveal that the two patterns differ only slightly in terms of their practical realization, but are highly variable between individuals. These variabilities are mainly rooted in the cattle herders' personal decisions about where, when and for how long they will move. For traditional transhumance, these decisions are mainly taken on the basis of technical factors like water and fodder availability, security, and logistics. In turn, inverse transhumance movements are to a far greater extent determined and constrained by informal institutions, especially mental models regarding concepts of hospitality, guest rights and kinship. As a consequence of differing personal interpretations of these concepts, the transhumance to the coastal plain is not undertaken by all potential participants who would gain from it in terms of security against cattle raiders. The following section discusses the institutional constraints on participation in inverse transhumance on the one hand, as well as the aspects that enabled the establishment of the movement on the other hand.

PROCEDURAL LIBERTY, MOBILITY, AND RISK PERCEPTION. The

inverse transhumance movement did not emerge through some process of collective decision-making on the village or clan level, but through the decisions of individual herders to start moving. The movement's development was facilitated by the herders' procedural liberty to start moving without the need for coordination with others outside the core family, and without having to wait for the establishment of some kind of formal agreement. There are also no social norms or taboos (fady) that restrain the move. The plateau herders arriving on the coastal plain were able to make use of region-wide institutions already used in the context of traditional transhumance, especially the sincerity oaths (titike, kine). Therefore, no formal agreements between plateau and coastal plain communities had to be established to allow the plateau herders to stay on the coastal plain. Also, for the annual moves, no local, regional or national formal institutions have to be considered, apart from the duty to register the stay in every herder's 'passport' at the chefs de fokontany.

The literature about the study area mentions frequent migration patterns not addressed in the interviews: Many women marry into another village, men temporarily move inside or outside regions to carry out slash-and-burn agriculture (SULAMA 2011) or to take up temporary employment (Neudert et al. 2015). Regional droughts and famines trigger the final out-migration of whole families (Kaufmann and Tsirahamba 2006). This overall high mobility supports taking a temporary move into account when searching for strategies for coping with raids. Not surprisingly, being bound to one's ancestral land was stated only once.

The main reason stated for not moving was the cattle's adaptation problems to the conditions on the coastal plain. Given that many plateau animals have survived a stay on the coastal plain over decades, it may initially seem surprising that herders rate the risk of mal-adaptation high enough to impede a move. But this reasoning can be explained firstly by a lack of information, since discussions on the conditions for staying on the coastal plain seldom seem to take place outside the circle of the core family. Secondly, especially in Andremba, this argument might be offered in place of real hidden motives, such as the lack of a guest right on the coastal plain.

GUEST RIGHTS AND THE WEAKENING OF UNCONDITIONAL HOSPITALITY. While herders on traditional transhumance move into a situation of fodder abundance on the plateau, on inverse transhumance to the coastal plain the cattle are fed mainly on the relatively scarce samata that often has to be bought. Thus, unlike other cases of seasonal migration (Fernandez-Gimenez and Le Febre 2006), inverse transhumance does not predominantly ease fodder scarcity, but leads to significantly higher fodder costs.

Besides buying most part of the fodder needed, guest herders on the coastal plain are allowed to take community samata free of charge. At the same time, inner-village conflicts on the distribution of samata are ongoing and guest herders in general have a bad reputation for selfishly overusing the samata trees. So, why do the villagers continue to provide guest herders with free access? First, the traditional Tanalana-Mahafaly society shares a social value and mental model of unconditional hospitality towards all guests, irrespective of whether they are kinsmen or not. This resembles the broader concept of fihavanana or nationwide solidarity (Kneitz 2014). However, the differing statements about not welcoming unknown herders from the plateau show that unconditional hospitality is today no longer part of all people's mental models. Second, the villagers often complained in interviews about the guest herders' use of community samata, but did not normally bring this topic to the community meetings. This may be because complaining in public disrupts the social value of harmony, as also observed in other regions of Madagascar (Fritz-Vietta et al. 2009, Hauge 2010). Third, if the guest herders come from the traditional transhumance areas on the plateau, many inhabitants of the coastal plain perceive a duty to reciprocate by receiving and providing the herders with free fodder.

Denying plateau herders without longo (relatives, friends) a stay on the coastal plain best illustrates the weakening of unconditional hospitality. The reason cited for the denial - fear of being robbed by unfamiliar guests - can also be attributed to the described perceived social change with deteriorating levels of trust and social cohesion. This change in the social environment has led to a modification of the traditionally shared mental models of 'the people love each other' and 'we are all one kin'. As described for other parts of Madagascar (Fauroux 1997, Ferraro 2002, Marcus 2008), the local unconditional hospitality shifts towards a narrower concept of kin including only people of the same descendancy (Bloch 1968, Keller 2009). From other pastoral societies around the world, social constraints on pastoral mobility and emerging conflicts are also known to be caused by narrowing or lacking solidarity and reciprocity (Finke 2000, Thébaud and Batterbury 2001, Beyene 2009).

VARIABILITIES IN MENTAL MODELS. As shown by the statements from the different interviewees, mental models of mobility, security, guest rights and kinship vary strongly and are often contradictory. On the one hand, many interviewees from both the 
plateau and the coastal plain viewed the stay on the coastal plain as restricted to the existence of longo. On the other hand, interviewees from both regions also negated this restriction. These contradicting mental models lead to a high variation in the herders' individual decisions: those with a mental model of formal kinship dominated by clans and lineages (raza) would never consider moving to a place where they have no raza people to stay with. Others move on the assumption of 'we are all one kin' regardless of different raza, or claim an informal guest right of all people, or at least the 'known' ones. This variety is due to a highly informal institutional setting. For herders with consistent entries in their 'passport', there are no formal institutions that directly frame the move, for example, local community rules (dina) or clear ancestors' rules (lilyn-draza). Explicit social norms or ancestors' customs (fomban-draza) that can help to form the individual's mental model of mobility are also very limited. It is only the knowledge about traditional transhumance that serves as a kind of template.

However, regardless of the different interpretations of the conditions for guest rights, most plateau herders base their decision about whether and where to move to on the existence of longo. This shows that they have a good knowledge of the fact that the villagers from the coastal plain are increasingly suspicious towards all unknown guests. But many plateau herders also expressed a great fear of being a victim themselves. Yet their risk assessment does not reflect the reality of the comparatively secure coastal plain where raids are rare. Instead, their mental model of the coastal plain seems to be a reflection of the insecure situation at home on the plateau.

\section{DIFFERENT DEGREES OF INSTITUTIONALIZATION. According to}

the literature on traditional transhumance, the guest rights for staying on the plateau are founded on royal agreements between the three former Mahafaly kingdoms (Battistini 1964), bonds of blood brotherhood (ziva) by Tanalana clan founders and Mahafaly people (Esoavelomandroso 1989), or, in the case of Andremba, familiar bonds (Armandine 1991). These agreements and bonds seem to have lost their practical relevance, as interviewees did not refer to them in the context of transhumance, and many guest herders staying in Andremba have de facto no relatives there. However, an unconditional, general guest right allowing all coastal herders to stay on the plateau was not questioned by either coastal or plateau interviewees. Most interviewees did not even think that being allowed to stay on the plateau needed justification. The only related argumentation is that transhumance to the plateau is the people's fomban-draza (ancestral tradition/custom). Traditional transhumance can thus be seen as a highly institutionalized practice. Whereas in the beginning it needed formal institutionalization by royal agreements or social bonds, today it is informally institutionalized through a shared mental model about the legitimate actions and roles of the involved actors (Berger and Luckmann 1966): Both the people from the coastal plain as well as the plateau consider traditional transhumance as a fomban-draza, and thus it is, together with fomba gasy (Malagasy custom), per definition the right thing to do (Evers 2006).

In contrast, inverse transhumance is still much less formally or informally institutionalized. There are several reasons for this: First, although the interviews reveal the simplicity of creating a 'new fomba', inverse transhumance has apparently not reached this institutionalized status. In other words, it still lacks the necessary period of continued existence for being perceived as morally just (Hodgson 1998). Second, as the social norm of unconditional hospitality and the mental model of broad kinship are no longer shared by all people, the potential for informal institutionalization is also limited. Third, inverse transhumance is realized and perceived as a kind of private affair. Unlike traditional transhumance, no collective action for formal institutionalization has taken place, for example by sincerity oath rituals (titike) between guest groups and the host communities. Thus, every guest herder has to institutionalize his personal stay in each host village by performing his own ritual.

\section{CONCLUSION}

This case study investigated the development of a new transhumance movement in the Mahafaly Plateau region in relation to the local socio-institutional context of formal and informal institutions, especially traditions and mental models about guest rights and kinship. The new movement in the inverse direction to the traditional transhumance movement turns out to be the main strategy for mitigating against worsening cattle raids. It is enabled and facilitated by herding families' decision-making freedom, traditional mechanisms of trust creation, and a shared concept of hospitality. Access to ancestral land (tanin-draza), and thus fodder and water, is found to be not a major constraint on pastoral mobility in this region. Limits to the movement arise from a change in the social environment mainly attributed to the cattle raids: The mental models of unconditional hospitality, good relations and broad kinship (filongoa, fihavanana) are increasingly replaced by much narrower conceptions of kinship and a kind of hospitality based on reciprocity. Therefore, many herders feel restricted in their decisions about where to move on transhumance, or if to move at all. Unlike the traditional transhumance movement, trust between moving herders and the communities at their destinations is a crucial precondition for deciding to move. Guest rights for moving herders are increasingly bound to the existence of longo-kin (relatives or friends) at the destination.

The present study demonstrates that individuals' adaptive capacity may differ considerably within the same social community. Adaptation options may depend on the individuals' mental models in the sense of the interpretation of the problem, the environment, and especially the society in which they live. In the case of the new transhumance movement, personal mental models enable adaptive action by some herders, while internally constraining others to undertake the same action. The range of diverse and sometimes contradictory mental models may be especially broad in the context of ongoing social change as presented here. Further research on adaptation should consider not only the framework of formal social institutions, but should also acknowledge the importance of underlying mental models.

\section{ACKNOWLEDGEMENTS}

I would like to thank all interviewees, my research assistants Andrianjohary Léopold Clément and Eltos Lazandrainy Fahamaro, my colleagues at BTU for fruitful feedback, as well as three anonymous reviewers for their critical and insightful comments on earlier versions of this paper. This research has been funded by the German Federal Ministry of Education and Research (BMBF) within the project SuLaMa (Sustainable Land management in Madagascar). 


\section{REFERENCES}

Adger, W. N., Dessai, S., Goulden, M., Hulme, M., Lorenzoni, I. et al. 2009. Are there social limits to adaptation to climate change? Climatic Change 93, 3-4: 335-354. (doi:10.1007/s10584-008-9520-z)

Agrawal, A. 2010. Local institutions and adaptation to climate change. In: Social Dimensions of Climate Change. Equity and Vulnerability in a Warming World. R. Mearns (ed.), pp 173-198. The World Bank, Washington, D.C.

Armandine 1991. Transhumance, polygamie, circulation des bœufs dans la plaine côtière et dans l'intérieur du pays Mahafale du Nord. In: Aombe 1: Cohésion Sociale, Modernité et Pression Démographique. M. Esoavelomandroso (ed.), pp 63-78. MRST and ORSTOM, Antananarivo.

Astuti, R. 1995. People of the Sea. Identity and descent among the Vezo of Madagascar. Cambridge University Press, Cambridge.

Battistini, R. 1964. Géographie Humaine de la Plaine Côtière Mahafaly. Thèse complémentaire de Doctorat es Lettres. Éditions Cujas, Paris.

BBC News 2008. Cattle 'war zone' in Madagascar. Available at <http://news.bbc.co.uk/2/hi/programmes/from_our_own_correspondent/7465726.stm>

Behnke, R. H., Fernandez-Gimenez, M. E., Turner, M. D. and Stammler, F. 2011. Pastoral migration. Mobile systems of livestock husbandry. In: Animal Migration - A Synthesis. E. J. Milner-Gulland, J. Fryxell and A. R. E. Sinclair (eds.), pp 144-252. Oxford University Press, Oxford.

Berger, P. L. and Luckmann, T. 1966. The Social Construction of Reality. A Treatise in the Sociology of Knowledge. Anchor Books, Garden City, New York.

Beyene, F. 2009. Property rights conflict, customary institutions and the state: The case of agro-pastoralists in Mieso district, eastern Ethiopia. The Journal of Modern African Studies 47, 2: 213-239. (doi:10.1017/S0022278X09003814)

Blench, R. 2001. 'You Can't Go Home Again'. Pastoralism in the New Millennium. Overseas Development Institute, London. Available at <http://ow.ly/TOgue>

Bloch, M. 1968. Tombs and Conservatism Among the Merina of Madagascar. Man, New Series 3, 1: 94-104. (doi:10.2307/2799414)

Bloch, M. 2005. Essays on Cultural Transmission. Berg Publishers, Oxford.

Bollig, M. 2006. Risk Management in a Hazardous Environment. A Comparative Study of two Pastoral Societies. Springer, New York.

Bromley, D. W. 2006. Sufficient Reason. Volitional Pragmatism and the Meaning of Economic Institutions. Princeton University Press, Princeton, Oxford.

Brousseau, E., Garrouste, P. and Raynaud, E. 2011. Institutional changes: Alternative theories and consequences for institutional design. Journal of Economic Behavior \& Organization 79, 1-2: 3-19. (doi:10.1016/j.jebo.2011.01.024)

Defoe, D., Oliver, S. P. and Rochon, A. 1890. Madagascar; or, Robert Drury's journal, during fifteen years' captivity on that island. T. Fisher Unwin, London. Available at <https://archive.org/stream/madagascarorrobe00defouoft\#page/n9/mode/2up>

Denzau, A. T. and North, D. C. 1994. Shared mental models: Ideologies and institutions. Kyklos 47, 1: 3-31. (doi:10.1111/j.1467-6435.1994.tb02246.x)

Dequech, D. 2006. Institutions and norms in institutional economics and sociology. Journal of Economic Issues 40, 2: 473-481.

Di Falco, S. and Bulte, E. 2013. The impact of kinship networks on the adoption of risk-mitigating strategies in Ethiopia. World Development 43: 100-110. (doi:10.1016/j.worlddev.2012.10.011)

Eggert, K. 1986. Mahafaly as misnomer. In: Madagascar. Society and History. C. P. Kottak, J.-A. Rakotoarisoa, A. Southall and P. Vérin (eds.), pp 321-353. Carolina Academic Press, Durham.

Eggertsson, T. 2013. Quick guide to new institutional economics. Journal of Comparative Economics 41, 1: 1-5. (doi:10.1016/j.jce.2013.01.002)

Elli, L. 1993. Une Civilisation du bœuf : Les Bara de Madagascar. Difficultés et perspectives d'une Évangélisation. Ambozontany, Fianarantsoa.

Esoavelomandroso, M. 1989. Territoires et troupeaux des Temitongoa. In: Histoire et Organisation de l'Espace à Madagascar. J. Fremigacci (ed.), pp 47-56. Karthala, Paris.

Evers, S. J. T. M. 2006. Expropriated from the hereafter: The fate of the landless in the Southern Highlands of Madagascar. Journal of Peasant Studies 33, 3: 413-444. (doi:10.1080/03066150601062928)
Evers, S. J. T. M. and Seagle, C. 2012. Stealing the sacred: Why 'global heritage' discourse is perceived as a frontal attack on local heritage-making in Madagascar. Madagascar Conservation \& Development 7, 2S: 97-106. (doi:10.4314/mcd.v7i2S.6)

Fafchamps, M. and Minten, B. 2006. Crime, Transitory Poverty, and Isolation: Evidence from Madagascar. Economic Development and Cultural Change 54, 3: 579-603. (doi:10.1086/500028)

Faublée, J. 1941. L'élevage chez les Bara du Sud de Madagascar. Journal de la Société des Africaines 11, 1: 115-123. Available at <http://www.persee.fr/doc/jafr_0037-9166_1941_num_11_1_2505>

Fauroux, E. 1989. Une étude pluridisciplinaire des sociétés pastorales de l'ensemble méridional de Madagascar. In : Les Dynamiques Internes de la Transformation Sociale. J. Lombard (ed.), pp 489-497. Cahier des Sciences Humaines 25, 4. Available at <http://www.documentation.ird.fr/hor/fdi:31560>

Fauroux, E. 1997. Les éleveurs de l'Ouest malgache face aux difficultés économiques du dernier quart du XXe siècle. Paper presented at the conference "Atelier Ménages et Crises", Marseille 24-26 March 1997. Available at $<$ http://Ow.ly/TOiPn>

Fauroux, E. 2003. Voleurs de bœufs, État et paysans dans l'ouest et le sud-ouest malgaches. Studia Africana 15: 16-45.

Fernandez-Gimenez, M. E. and Le Febre, S. 2006. Mobility in pastoral systems: Dynamic flux or downward trend? International Journal of Sustainable Development \& World Ecology 13, 5: 341-362. (doi:10.1080/13504500609469685)

Ferraro, P. J. 2002. The local costs of establishing protected areas in low-income nations: Ranomafana National Park, Madagascar. Ecological Economics 43, 2-3: 261-275. (doi:10.1016/S0921-8009(02)00219-7)

Fieloux, M. 1987. Une étude ethno-historique des impacts sociaux de la crise de l'élevage. In: L'Équipe Madagascar. Une Expérience de Coopération, une Équipe de Recherche 1985-1987. J. Lombard (ed.), pp 67-68. ORSTOM, Paris. Available at <http://www.documentation.ird.fr/hor/fdi:27515>

Finke, P. 2000. From 'Common Property' to Open Access: Changing Pastoral Land Tenure in Post-Socialist Mongolia. Paper presented at the conference "Constituting the Commons: Crafting Sustainable Commons in the New Millennium, the Eighth Biennial Conference of the International Association for the Study of Common Property", May 31-June 4 2000, Bloomington, Indiana, USA. Available at <http://ow.ly/TOjpw>

Fritz-Vietta, N., Röttger, C. and Stoll-Kleemann, S. 2009. Community-based management in two biosphere reserves in Madagascar - distinctions and similarities: What can be learned from different approaches? Madagascar Conservation \& Development 4, 2: 86-97. (doi:10.4314/mcd.v4i2.48648)

Fritz-Vietta, N. V. M., Ferguson, H. B., Stoll-Kleemann, S. and Ganzhorn, J. U. 2011. Conservation in a biodiversity hotspot: Insights from cultural and community perspectives in Madagascar. In: Biodiversity Hotspots. Distribution and Protection of Conservation Priority Areas. F. E. Zachos and J. C. Habel (eds.), pp 235-280. Springer, Berlin, Heidelberg.

Hauge, W. 2010. When peace prevails: the management of political crisis in Ecuador, Madagascar, Tunisia, and Venezuela. Alternatives: Global, Local, Political 35, 4: 469-493. (doi:10.1177/030437541003500407)

von Heland, J. and Folke, C. 2014. A social contract with the ancestors-Culture and ecosystem services in southern Madagascar. Global Environmental Change 24: 251-264. (doi:10.1016/j.gloenvcha.2013.11.003)

Hodgson, G. M. 1998. The approach of institutional economics. Journal of Economic Literature 36: 166-192. Available from <http://www.geoffrey-hodgson.info/user/image/approachinec.pdf>

Hodgson, G. M. 2006. What are institutions? Journal of Economic Issues 40, 1: 1-26. Available from <http://www.geoffrey-hodgson.info/user/image/whatareinstitutions.pdf>

Hoerner, J. M. 1982. Le vol de bœufs dans le Sud-Ouest de Madagascar. Madagascar Revue de Géographie 41: 45-105.

Kaufmann, J. C. 1998. The cactus was our kin: Pastoralism in the spiny desert of southern Madagascar. In: Changing Nomads in a Changing World. J. Ginat and A. M. Khazanov (eds.), pp 124-142. Sussex Academic Press, Brighton \& Portland, Oregon.

Kaufmann, J. C. 2004. Prickly pear cactus and pastoralism in southwest Madagascar. Ethnology 43, 4: 345-361. (doi:10.2307/3774032) 
Kaufmann, J. C. and Tsirahamba, S. 2006. Forests and thorns: conditions of change affecting Mahafale pastoralists in southwestern Madagascar. Conservation and Society 4, 2: 231-261.

Keller, E. 2009. The danger of misunderstanding 'culture'. Madagascar Conservation \& Development 4, 2: 82-85. (doi:10.4314/mcd.v4i2.48647)

Kneitz, P. 2014. Introduction. La paix du fihavanana. In: Fihavanana. La Vision d'une Société Paisible à Madagascar. P. Kneitz (ed.), pp 15-72. Universitaetsverlag Halle-Wittenberg, Halle an der Saale.

Knight, J. and North, D. C. 1997. Explaining economic change: The interplay between cognition and institutions. Legal Theory 3, 3: 211-226. (doi:10.1017/S1352325200000768)

Knight, J. and Sened, I. 1995. Introduction. In: Explaining Social Institutions. J. Knight and I. Sened (eds.), pp 1-13. University of Michigan Press, Ann Arbor.

Mantzavinos, C., North, D. C. and Shariq, S. 2004. Learning, institutions, and economic performance. Perspectives on Politics 2, 1: 75-84. (doi:10.1017/\$1537592704000635)

Marcus, R. R. 2008. Tòkana: the collapse of the rural Malagasy community. African Studies Review 51, 1: 85-104. (doi:10.1353/arw.0.0046)

MCNair, J. 2008. Romancing Dahalo: The Social Environment of Cattle Theft in Ihorombe, Madagascar. Independent Study Project (ISP) Collection Paper 69. Available from <http://digitalcollections.sit.edu/isp_collection/69>

Michel, L. 1957. Mœurs et Coutumes des Bara. Imprimerie Officielle, Antananarivo.

Muttenzer, F. 2006. The folk conceptualisation of property and forest-related going concerns in Madagascar. In: Changing Properties of Property. F. von BendaBeckmann, K. von Benda-Beckmann and M. G. Wiber (eds.), pp 269-292. Berghahn Books, New York, Oxford.

Neudert, R., Goetter, J. F., Andriamparany, J. N. and Rakotoarisoa, M. 2015. Income diversification, wealth, education and wellbeing in rural south-western Madagascar: Results from the Mahafaly Region. Development Southern Africa, Online August 2015. (doi:10.1080/0376835X.2015.1063982)

OCHA reliefweb, 21.06.2012. Madagascar: Dahalo Attack Displaces People in the South, Situation Update. Available at <http://reliefweb.int/map/madagascar/madagascar-dahalo-attack-displaces-people-south-situation-update-21-june-2012>

Ostrom, E. 2005. Understanding Institutional Civersity. Princeton University Press, Princeton.

Patton, M. Q. 2002. Qualitative Research \& Evaluation Methods. SAGE, London.

Rabearison, J. J. 1965. Les Voleurs de Bœufs. Imprimerie Luthérienne Antsahamanitra, Antananarivo.

Rakoto, I. 2010. L'insécurité rurale liée au vol de bœufs : quelques propositions de solution. Taloha 19: 1-10

Rakoto, I. 2011. La problématique de l'application du droit en matière de vol de bœufs à Madagascar (1787-1960). Taloha 20: 1-10

Randrianarison, J. 1976. Le bœuf dans l'économie rurale de Madagasacr. Les problèmes de l'intégration de l'élevage bovin dans l'économie nationale. Madagascar: Revue de Géographie 29: 9-81.

Randrianjafizanaka, A. 1973. Le vol de bœufs. Terre Malgache 14, 151-171.

Rasamoelina, H. 2006. Madagascar. État, Communautés Villageoises et Banditisme Rural. L'Exemple du Vol de Zébus dans la Haute-Matsiatra. L'Harmattan, Paris.

Ribar, E. 1926. Le vol de bœufs dans le Sud-Ouest de Madagascar. Bulletin de I'Académie Malgache $9:$ 39-52.

de Saint-Sauveur, A. 2002. Prévention des vols de bétail chez les agropasteurs Bara de Madagascar. Une conception défensive du patrimoine. In: Patrimonialiser la Nature Tropicale : Dynamiques Locales, Enjeux Internationaux. M.-C. Cormier Salem, D. Juhé-Beaulaton, J. Boutrais and B. Roussel (eds.), pp 245-258. IRD Editions, Paris

Schachenmann, P. 2006. Spiritual values in Madagascar: the starting point for endogenous conservation initiatives. Mountain Research and Development 26, 4: 323-327. (doi:10.1659/0276-4741\%282006\%2926\%5B323\%3ASVIM\%5D2.0.CO\%3B2)
Scheffran, J., Marmer, E. and Sow, P. 2011. Migration as a contribution to resilience and innovation in climate adaptation: Social networks and co-development in Northwest Africa. Applied Geography 33, 1: 119-127. (doi:10.1016/j.apgeog.2011.10.002)

Scheidecker, G. 2014. Cattle, conflicts, and gendarmes in southern Madagascar: A local perspective on fihavanana gasy. In: Fihavanana. La Vision d'une Société Paisible à Madagascar. P. Kneitz (ed.), pp 129-156. Universitaetsverlag Halle-Wittenberg, Halle an der Saale.

Schilling, J., Opiyo, F. E. and Scheffran, J. 2012. Raiding pastoral livelihoods: motives and effects of violent conflict in north-western Kenya. Pastoralism: Research, Policy and Practice 2, 1: \#25. (doi:10.1186/2041-7136-2-25)

Schmid, A. A. 2004. Conflict and Cooperation. Institutional and Behavioral Economics. Blackwell, Malden, Oxford, Carlton.

Southall, A. 1986. Common themes in Malagasy culture. In: Madagascar. Society and History. C. P. Kottak, J.-A. Rakotoarisoa, A. Southall and P. Vérin (eds.), pp 410-438. Carolina Academic Press, Durham, South Carolina.

SULAMA 2011. Diagnostic participatif de la gestion des ressources naturelles sur le plateau Mahafaly Commune Rurale de Beheloka - Toliara. Rapport Final. SULAMA, Tuléar. Available at <http://ow.ly/TOvdy>

Thébaud, B. and Batterbury, S. 2001. Sahel pastoralists: Opportunism, struggle, conflict and negotiation. A case study from eastern Niger. Global Environmental Change 11, 1: 69-78. (doi:10.1016/S0959-3780(00)00046-7)

Tubau, M. R. 2011. Les pratiques traditionnelles au service des paysans pour la prévention des vols de zébus. L'exemple du tatao et du tsitsika dans le district de I'Isandra, Haute Matsiatra. Taloha 20: 1-9.

Upton, C. 2012. Adaptive capacity and institutional evolution in contemporary pastoral societies. Applied Geography 33: 135-141. (doi:10.1016/j.apgeog.2011.10.008)

Vatn, A. 2005. Institutions and the Environment. Edwar Elgar, Cheltenham, Northampton.

\section{SUPPLEMENTARY MATERIAL.}

AVAILABLE ONLINE ONLY.

TABLE S1. Time frames and number of interviewees indicating the start of cattle raiding as a problem and the start of inverse transhumance. 